\title{
KEANEKARAGAMAN TUMBUHAN OBAT MASYARAKAT DI HUTAN TALANG RENCONG DESA PULAU SANGKAR, KABUPATEN KERINCI, JAMBI
}

\author{
(Diversity of Medicinal Plants in The Forest Talang Rencong Village Island Cage, \\ Regency Kerinci, Jambi)
}

\author{
ADE ADRIADI ${ }^{1 *}$, NURSANTI ${ }^{2)}$ DAN RIKE PUSPITASARI $^{2)}$ \\ ${ }^{1)}$ Program Studi Biologi, Fakultas Sains dan Teknologi, Universitas Jambi, Muaro Jambi, Indonesia 36361 \\ ${ }^{2)}$ Fakultas Kehutanan Universitas Jambi, Muaro Jambi, Indonesia 36361 \\ *Email: adeadriadi@unja.ac.id
}

Diterima 12 Oktober 2019 / Disetujui 04 Juni 2020

\begin{abstract}
Indonesia has approximately 30,000 species of medicinal plants based on the richness of the flora. Indonesia has the great potential to develop herbal products that are equivalent to modern medicine. The modern treatment has not been reachable by the whole community in Indonesia, only about $25 \%$ affordable and the rest are not yet affordable. The role of traditional medicine recipes become much helpful especially for people living in remote areas with minimal access. The research was conducted in April-May 2019 at Talang Rencong Traditional forest, Pulau Cage Village, Kerinci Regency, Jambi. The sample area of research was $1 \mathrm{Ha}$, or $5 \%$ of total area. The methods used in this research were participatory exploration and observation, data collection was conducted by tracing indigenous forests accompanied by local communities (Data is analyzed from any species found during research). The research in the indigenous forest Talang Rencong village Pulau Cage, Kerinci Regency, Jambi acquired 23 familia and 39 species of medicinal plants used. How to use from the herbs are divided into 25 species of medicinal plants that use drinkable, 6 species of medicinal plants are applied or pasted, 4 species of herbs are directly consumed, 1 species of medicinal plants is used to be washed, 2 species of medicinal plants used to be dipped in the eyes and 1 type of medicinal plants that use the input into perforated teeth The benefits of such medicinal plants are as breast cancer medicine, relieves itching for children, nail health remedy, uric acid medecine, removal bruising, uterine watering, appetite enhancer, diarrhea, toothache medications, jaundice medications, cough medicines, shortness of breath medication for infants, deep heat medications, reducing blood sugar levels, paralysis medications, lowering cholesterol, and medication for postnatal blood and uric acid.
\end{abstract}

Keywords: ethnobotany, medicinal plants, Rencong customary forest

\begin{abstract}
ABSTRAK
Indonesia memiliki sekitar 30.000 jenis tumbuhan obat, berdasarkan kekayaan flora tersebut tentu Indonesia memiliki potensi untuk mengembangkan produk herbal yang kualitasnya setara dengan obat modern. Pengobatan modern pada masyarakat di Indonesia belum dapat dijangkau oleh seluruh kalangan masyarakat, hanya sekitar 25\% terjangkau dan sisanya belum terjangkau. Peranan resep obat tradisional sangat banyak membantu khususnya untuk masyarakat yang tinggal di kawasan terpencil yang minim akses. Penelitian dilakukan pada bulan April-Mei 2019 di Hutan Adat Talang Rencong, Desa Pulau Sangkar, Kabupaten Kerinci, Jambi. Luas areal penelitian yang diambil yaitu 1 Ha, atau 5\% dari luas total. Metode yang digunakan adalah metode eksplorasi dan observasi partisipatif, pengumpulan data dilakukan dengan menelusuri hutan adat dengan didampingi masyarakat lokal. Hasil penelitian menunjukkan jenis tumbuhan obat yang digunakan sebanyak 39 jenis dari 23 famili. Cara penggunaan tumbuhan obat terdiri dari diminum (25 jenis), dioleskan atau ditempel (6 jenis), dimakan langsung (4 jenis), dimandikan (1 jenis), dicelupkan mata (2 jenis) dan dimasukan ke gigi berlubang (1 jenis). Manfaat dari tanaman obat tersebut adalah sebagai obat kanker payudara, gatal pada anak, kesehatan kuku, asam urat, menghilangkan memar, penyubur rahim, penambah nafsu makan, diare, sakit gigi, penyakit kuning, batuk, sesak napas untuk bayi, panas dalam, menurunkan kadar gula, lumpuh, menurunkan kolesterol, mengeluarkan darah kotor pasca melahirkan dan asam urat.
\end{abstract}

Kata kunci: etnobotani, Hutan Adat Rencong, tumbuhan obat 


\section{PENDAHULUAN}

Indonesia dikenal dengan kekayaan flora, di antaranya terdiri dari tumbuhan obat sekitar 30.000 spesies dari total 40.000 spesies tumbuhan di dunia, 940 spesies di antaranya merupakan tumbuhan berkhasiat obat (Masyhud 2010). Oleh sebab itu, Indonesia berpotensi untuk menjadikan tumbuhan obat tradisional yang memiliki kualitas setara dengan obat modern (Johnherf 2007). Tumbuhan obat telah dikenal sejak dahulu dan dimanfaatkan oleh bangsa Indonesia untuk menanggulangi masalah kesehatan sampai saat ini.

Pada saat ini pengobatan modern di Indonesia hanya terjangkau sekitar $25 \%$ sedangkan $75 \%$ masih belum terjangkau. Peranan resep obat tradisional sangat banyak membantu khususnya untuk masyarakat yang tinggal di kawasan terpencil karena kesulitan transportasi. Masyarakat mengonsumsi tumbuhan yang digunakan untuk obat sebagai pertolongan pertama ketika menderita sakit. Selain itu, masyarakat juga biasanya memiliki stok bahan kering dari berbagai tumbuhan yang akan dimanfaatkan sebagai kewaspadaan terhadapa sakit yang datangnya tidak menentu (Kuni et al. 2015).

Obat tradisional bukan merupakan sesuatu yang baru untuk penduduk Indonesia. Bahan baku obat tradisional banyak tersedia di Indonesia, selain itu cara mengelola obat tradisional sudah diajarkan turuntemurun. Hidup sehat sangat diperlukan dalam kehidupan sehari-hari. Saat ini kesadaran dan kebutuhan masyarakat tentang hidup sehat mulai meningkat, di antaranya sudah mulai mengonsumsi makanan sehat tanpa menggunakan bahan-bahan kimia sintesis. Gaya hidup sehat alami atau lebih dikenal dengan kembali ke alam bisa menghasilkan kesehatan yang sangat bagus. Salah satu gaya hidup sehat atau kembali kealam yang dilakukan adalah penggunaan tumbuhan sebagai obat tradisional yang dikenal dengan istilah "Jamu" di Indonesia. Istilah jamu secara internasional dikenal dengan nama Herbal Medicine (Kardinan dan Ruhnayat 2003).

Menurut Jaini (1993), bagian pada tumbuhan seperti akar, batang, daun, kulit, umbi, biji, getah dan buah yang memiliki khasiat obat biasanya digunakan sebagai bahan mentah untuk pembuatan obat tradisional maupun modern. Obat dari tumbuhan berdasarkan cara pembuatannya dapat dikelompokkan menjadi dua, yaitu obat modern dan tradisional. Obat tradisional tidak menggunakan bahan kimia sedangkan obat modern menggunakan bahan kimia dalam pembuatannya. Warisan budaya dari pemanfaatan tumbuhan obat yang digunakan sebagai obat telah dilakukan secara turun temurun berdasarkan pengetahuan dan pengalaman yang diwariskan dari generasi sebelumnya, sehingga akan terbentuk ramuan obat yang berkualitas tinggi.

Kabupaten Kerinci terletak di Provinsi Jambi pada $01^{\circ} 40^{\prime}$ dan $02^{\circ} 26^{\prime}$ Lintang Selatan, serta $101^{\circ} 08^{\prime}$ sampai dengan 101 $50^{\prime}$ ' Bujur Timur dengan luas wilayah Kabupaten Kerinci yaitu sebesar 332.807 Ha atau
$3328,14 \mathrm{~km}^{2}$. Kabupaten Kerinci memiliki 16 kecamatan dan 285 desa dengan total luas wilayah $3.328 .14 \mathrm{~km}^{2}$. Salah satu kecamatan yang ada di Kabupaten Kerinci adalah Kecamatan Batang Merangin yang memiliki luas $476.46 \mathrm{~km}^{2}$ yang terdiri atas sembilan desa, salah satunya adalah Desa Pulau Sangkar. Berdasarkan data di kantor Desa Pulau Sangkar, masyarakat menggunakan tumbuhan untuk dijadikan obat dalam kehidupan seharihari. Masyarakat Desa Pulau Sangkar banyak mengambil tumbuhan untuk dijadikan obat dalam kehidupan sehari di hutan adat yang ada di desa tersebut, hutan adat tersebut dikenal dengan nama Hutan Adat Talang Rencong. Hutan Adat tersebut cukup dekat dengan pemukiman masyarakat namun jalan ke hutan tersebut cukup terjal. Masyarakat tetap menempuh jalan ke hutan adat tersebut karena sangat membutuhkan tumbuhan yang akan dijadikan obat. Hutan Adat Talang Rencong memiliki keanekaragaman tumbuhan yang cukup banyak. Namun penelitian mengenai keanekaragaman jenis tumbuhan yang dimanfaatkan oleh masyarakat Desa Pulau Sangkar di hutan adat Talang Rencong belum ada. Oleh karena itu perlu dilakukan penelitian mengenai "Keanekaragaman Tumbuhan Obat Masyarakat di Hutan Adat Talang Rencong Desa Pulau Sangkar, Kabupaten Kerinci, Jambi"

\section{METODE PENELITIAN}

Penelitian dilakukan pada bulan April-Mei 2019. Lokasi penelitian di Hutan Adat Talang Rencong Desa Pulau Sangkar. Kegiatan yang dilakukan selama penelitian meliputi survei lokasi, izin dengan kepala desa, bertanya dengan beberapa orang masyarakat Desa Pulau Sangkar terkait orang pintar/dukun di desa tersebut, pengambilan sampel di lapangan serta proses pembuatan herbarium. Metode yang digunakan adalah metode eksplorasi dan observasi partisipatif. Selanjutnya data spesies tumbuhan diidentifikasi dengan menggunakan buku panduan, literatur dan jika tidak teridentifikasi tumbuhan dikirim ke Herbarium ANDA Biologi Universitas Andalas Padang.

Pengumpulan data dilakukan dengan menelusuri hutan adat didampingi oleh 3 orang warga desa ( 2 warga yang disebut orang pintar/dukun dan 1 pemandu jalan). Dukun merupakan orang yang mengerti tentang tumbuhan obat di desa tersebut sedangkan pemandu jalan adalah pengurus hutan adat tersebut. Luas total Hutan Adat Talang Rencong menurut data dari penduduk setempat sekitar $20 \mathrm{Ha}$, sehingga untuk penelitian ini diambil $1 \mathrm{Ha}$ atau $5 \%$ dari luas total. Jenis tumbuhan yang diambil dan dibuat herbarium selama observasi partisipatif adalah jenis-jenis tumbuhan yang biasa digunakan masyarakat setempat untuk dijadikan obat.

Sampel tumbuhan kemudian diidentifikasi dengan berkonsultasi dan diskusi bersama ahli (dosen yang menguasai botani atau taxonomi tumbuhan) dan menggunakan buku-buku identifikasi flora contohnya 
buku flora, taksonomi tumbuhan dan Plant list. Sebanyak 12 jenis (dari 39 jenis) yang tidak teridentifikasi dikirim ke herbarium ANDA Biologi, Padang. Selain data jenis tumbuhan, data lain yang diambil adalah kegunaan dan cara pengelolaan dari tumbuhan obat tersebut.

\section{HASIL DAN PEMBAHASAN}

Berdasarkan hasil penelitian, jenis tumbuhan obat yang yang dimanfaaatkan oleh masyarakat Desa Pulau Sangkar Kecamatan Batang Merangin Kabupaten Kerinci sebanyak 39 jenis dari 23 famili (Tabel. 1).

Tabel 1 Jenis tumbuhan obat yang digunakan oleh Masyarakat Desa Pulau Sangkar Kecamatan Batang Merangin Kabupaten Kerinci

\begin{tabular}{|c|c|c|c|c|c|c|}
\hline No & Famili & Nama latin & Nama lokal & $\begin{array}{l}\text { Bagian yang } \\
\text { dimanfaatkan }\end{array}$ & $\begin{array}{l}\text { Cara } \\
\text { penggunaan }\end{array}$ & Khasiat \\
\hline 1 & Annonaceae & Annona muricata L. & Sirsak & Daun & $\begin{array}{l}\text { Dikeringkan lalu } \\
\text { dicampurkan air } \\
\text { hangat + } \\
\text { diminum }\end{array}$ & $\begin{array}{l}\text { Obat menurunkan } \\
\text { kolesterol }\end{array}$ \\
\hline 2 & Apiaceae & Centella asiatica (L.) Urb. & Pegagan & $\begin{array}{l}\text { Semua bagian } \\
\text { tumbuhan }\end{array}$ & $\begin{array}{l}\text { Direbus dan air } \\
\text { nya diminum }\end{array}$ & $\begin{array}{l}\text { Obat sakit } \\
\text { pinggang }\end{array}$ \\
\hline 3 & & $\begin{array}{l}\text { Alstonia angustifolia } \\
\text { Wall. ex A.DC. }\end{array}$ & Pulai & $\begin{array}{l}\text { Kulit batang } \\
\text { dan daun }\end{array}$ & $\begin{array}{l}\text { Dijemur dan } \\
\text { direbus air nya } \\
\text { diminum }\end{array}$ & Obat malaria \\
\hline 4 & & Allamanda cathartica $\mathrm{L}$. & Alamanda & Daun & $\begin{array}{l}\text { Diremas + air } \\
\text { panas }+ \\
\text { diminum }\end{array}$ & Obat panas dalam \\
\hline 5 & Arecaceae & $\begin{array}{l}\text { Arenga pinnata } \\
(\text { Wurmb) Merr. }\end{array}$ & Enau & Gula & $\begin{array}{l}\text { Direbus dan air } \\
\text { nya diminum }\end{array}$ & Obat batuk \\
\hline 6 & Asteraceae & Ageratum conyzoides (L.) L. & Bandotan & Daun & $\begin{array}{l}\text { Direbus dan air } \\
\text { nya diminum }\end{array}$ & Obat kembung \\
\hline 7 & & $\begin{array}{l}\text { Austroeupatorium inulaefolium } \\
\text { (Kunth) RM.King \& H.Rob. }\end{array}$ & Kirinyuh & Daun & $\begin{array}{l}\text { Ditumbuk- } \\
\text { tumbuk, } \\
\text { ditempelkan } \\
\text { ketempat yang } \\
\text { luka }\end{array}$ & Obat luka \\
\hline 8 & & Bidens pilosa L. & Ajeran & $\begin{array}{l}\text { Semua bagian } \\
\text { tumbuhan }\end{array}$ & $\begin{array}{l}\text { Direbus dan air } \\
\text { nya diminum }\end{array}$ & $\begin{array}{l}\text { Obat } \\
\text { menghilangkan } \\
\text { pegal-pegal }\end{array}$ \\
\hline 9 & & $\begin{array}{l}\text { Crassocephalum crepidioides } \\
\text { (Benth.) S.Moore }\end{array}$ & Sintrong & $\begin{array}{l}\text { Semua bagian } \\
\text { tumbuhan }\end{array}$ & $\begin{array}{l}\text { Direbus dan air } \\
\text { nya diminum }\end{array}$ & $\begin{array}{l}\text { Obat } \\
\text { menghilangkan } \\
\text { pegal-pegal }\end{array}$ \\
\hline 10 & & $\begin{array}{l}\text { Emilia sonchifolia } \\
\text { (L.) DC. Ex DC. }\end{array}$ & $\begin{array}{l}\text { Tempuh } \\
\text { wiyang }\end{array}$ & $\begin{array}{l}\text { Semua bagian } \\
\text { tumbuhan }\end{array}$ & $\begin{array}{l}\text { Direbus dan } \\
\text { airnya diminum }\end{array}$ & $\begin{array}{l}\text { Obat sakit } \\
\text { pinggang }\end{array}$ \\
\hline 11 & & Erigeron sumatrensis Rets. & Jabung & Daun & $\begin{array}{l}\text { Ditumbuk- } \\
\text { tumbuk, } \\
\text { ditempelkan ke } \\
\text { mata }\end{array}$ & Obat sakit mata \\
\hline 12 & Campanulaceae & Laurentia longiflora Schltr. & $\mathrm{Ki}$ tolod & Bunga & $\begin{array}{l}\text { Direndam } \\
\text { dengan air panas } \\
+ \text { celupkan mata }\end{array}$ & Obat katarak \\
\hline 13 & Clusiaceae & Garcinia $s p$ & Manggis & Kulit batang & $\begin{array}{l}\text { Direbus dan air } \\
\text { nya diminum }\end{array}$ & Obat malaria \\
\hline 14 & Euphorbiaceae & $\begin{array}{l}\text { Aleurites moluccanus } \\
\text { (L.) Willd. }\end{array}$ & Kemiri & Buah & $\begin{array}{l}\text { Dikunyah } \\
\text { langsung }\end{array}$ & $\begin{array}{l}\text { Obat kesehatan } \\
\text { gigi }\end{array}$ \\
\hline 15 & & $\begin{array}{l}\text { Claoxylon longifolium } \\
\text { (Blume) Endl. ex Hassk. }\end{array}$ & $\begin{array}{l}\text { Pokok } \\
\text { salang }\end{array}$ & Daun & $\begin{array}{l}\text { Diremas }+ \\
\text { dicampur kelapa } \\
\text { yang sudah } \\
\text { diparut }+ \\
\text { diminum }\end{array}$ & Obat sembelit \\
\hline 16 & & Macaranga sp. & Mahang & Daun & $\begin{array}{l}\text { Dipanaskan } \\
\text { diatas api + } \\
\text { minyak sayur + } \\
\text { ditempelkan }\end{array}$ & Obat luka \\
\hline 17 & & $\begin{array}{l}\text { Mallotus paniculatus. } \\
\text { (Lam.) Mull.Arg }\end{array}$ & $\begin{array}{l}\text { Balik } \\
\text { Angin }\end{array}$ & Daun & $\begin{array}{l}\text { Direndam } \\
\text { dengan air panas } \\
+ \text { celupkan mata }\end{array}$ & Obat sakit mata \\
\hline
\end{tabular}


Tabel 1 Jenis tumbuhan obat yang digunakan oleh Masyarakat Desa Pulau Sangkar Kecamatan Batang Merangin Kabupaten Kerinci (Lanjutan)

\begin{tabular}{|c|c|c|c|c|c|c|}
\hline No & Famili & Nama latin & Nama lokal & $\begin{array}{l}\text { Bagian yang } \\
\text { dimanfaatkan }\end{array}$ & $\begin{array}{l}\text { Cara } \\
\text { penggunaan }\end{array}$ & Khasiat \\
\hline 18 & Lauraceae & Persea americana Mill. & Alpukat & Daun & $\begin{array}{l}\text { Direbus dan air } \\
\text { nya diminum }\end{array}$ & $\begin{array}{l}\text { Obat menurunkan } \\
\text { tensi }\end{array}$ \\
\hline 19 & Leguminosae & Cajanus cajan (L.) Millsp. & $\begin{array}{l}\text { Kacang } \\
\text { Gude }\end{array}$ & Daun & $\begin{array}{l}\text { Dikeringkan + } \\
\text { disiram air panas } \\
+ \text { diminum }\end{array}$ & $\begin{array}{l}\text { Obat pembekuan } \\
\text { darah }\end{array}$ \\
\hline 20 & & Cassia sp. & Johar & Daun & $\begin{array}{l}\text { Ditumbuk- } \\
\text { tumbuk + } \\
\text { Oleskan }\end{array}$ & Obat panu \\
\hline 21 & Loranthaceae & $\begin{array}{l}\text { Dendrophthoe falcata (L.f.) } \\
\text { Ettingsh }\end{array}$ & $\begin{array}{l}\text { Benalu } \\
\text { mangga }\end{array}$ & $\begin{array}{l}\text { Semua bagian } \\
\text { tumbuhan }\end{array}$ & $\begin{array}{l}\text { Disiram dengan } \\
\text { air panas dan } \\
\text { airnya diminum }\end{array}$ & $\begin{array}{l}\text { Obat kanker } \\
\text { payudara }\end{array}$ \\
\hline 22 & & $\begin{array}{l}\text { Dendrophthoe pentandra (L.) } \\
\text { Miq. }\end{array}$ & $\begin{array}{l}\text { Benalu } \\
\text { cengkeh }\end{array}$ & $\begin{array}{l}\text { Semua bagian } \\
\text { tumbuhan }\end{array}$ & $\begin{array}{l}\text { Direbus dan } \\
\text { airnya diminum }\end{array}$ & $\begin{array}{l}\text { Obat gatal pada } \\
\text { anak }\end{array}$ \\
\hline 23 & & $\begin{array}{l}\text { Scurrula ferruginea (Jack) } \\
\text { Danser }\end{array}$ & Benalu kopi & $\begin{array}{l}\text { Semua bagian } \\
\text { tumbuhan }\end{array}$ & $\begin{array}{l}\text { Direbus dan } \\
\text { airnya diminum }\end{array}$ & $\begin{array}{l}\text { Obat gatal pada } \\
\text { anak }\end{array}$ \\
\hline 24 & Lythraceae & Lawsonia inermis L. & Pacar kuku & Daun & $\begin{array}{l}\text { Digiling + } \\
\text { ditempel dikuku }\end{array}$ & $\begin{array}{l}\text { Obat kesehatan } \\
\text { kuku }\end{array}$ \\
\hline 25 & Malvaceae & Sida rhombifolia $\mathrm{L}$. & Sidaguri & Akar & $\begin{array}{l}\text { Direbus dan } \\
\text { airnya diminum }\end{array}$ & Obat asam urat \\
\hline 26 & & Urena lobata L. & Pulutan & Bunga & $\begin{array}{l}\text { Ditumbuk- } \\
\text { tumbuk, } \\
\text { ditempelkan } \\
\text { ketempat yang } \\
\text { memar }\end{array}$ & $\begin{array}{l}\text { Obat } \\
\text { menghilangkan } \\
\text { memar }\end{array}$ \\
\hline 27 & Melastomataceae & Melastoma malabathricum L. & Sikaduduk & Daun & $\begin{array}{l}\text { Direbus dan } \\
\text { airnya diminum }\end{array}$ & $\begin{array}{l}\text { Obat penyubur } \\
\text { rahim }\end{array}$ \\
\hline 28 & Meliaceae & Lansium sp. & Duku & Daun & $\begin{array}{l}\text { Direbus dan } \\
\text { airnya diminum }\end{array}$ & $\begin{array}{l}\text { Obat penambah } \\
\text { nafsu makan }\end{array}$ \\
\hline 29 & Myrtaceae & Psidium guajava $\mathrm{L}$. & Jambu Biji & Pucuk & $\begin{array}{l}\text { Dijemur kering } \\
\text { dan dimakan }\end{array}$ & Obat diare \\
\hline 30 & & $\begin{array}{l}\text { Syzygium aromaticum (L.) Merr. } \\
\text { \& L.M.Perry }\end{array}$ & Cengkeh & Buah & $\begin{array}{l}\text { Dimasukan ke } \\
\text { gigi yang } \\
\text { berlobang }\end{array}$ & Obat sakit gigi \\
\hline 31 & Phyllanthaceae & Bischojia javanica Blume & Gadog & Kulit batang & $\begin{array}{l}\text { Direbus dan } \\
\text { airnya diminum }\end{array}$ & $\begin{array}{l}\text { Obat penyakit } \\
\text { kuning }\end{array}$ \\
\hline 32 & Piperaceae & Piper betle L. & Sirih & Daun & $\begin{array}{l}\text { Direbus dan } \\
\text { airnya diminum }\end{array}$ & Obat batuk \\
\hline 33 & Poaceae & Eleusine indica (L.) Gaertn. & $\begin{array}{l}\text { Rumput } \\
\text { Belulang }\end{array}$ & Akar & $\begin{array}{l}\text { Disiram dengan } \\
\text { air panas dan } \\
\text { airnya diminum }\end{array}$ & $\begin{array}{l}\text { Obat sesak napas } \\
\text { untuk bayi }\end{array}$ \\
\hline 34 & & $\begin{array}{l}\text { Imperata cylindrica }(\mathrm{L} .) \\
\text { Raeusch. }\end{array}$ & Ilalang & Akar & $\begin{array}{l}\text { Direbus dan } \\
\text { airnya diminum }\end{array}$ & Obat panas dalam \\
\hline 35 & & Saccharum spontaneum L. & Gelagah & Batang & $\begin{array}{l}\text { Dipotong-potong } \\
\text { kecil, } \\
\text { dibersihkan }+ \\
\text { direbus }+ \\
\text { diminum }\end{array}$ & $\begin{array}{l}\text { Obat menurunkan } \\
\text { kadar gula }\end{array}$ \\
\hline 36 & Rubiaceae & Morinda citrifolia $\mathrm{L}$. & Mengkudu & Daun & $\begin{array}{l}\text { Direbus dan } \\
\text { airnya } \\
\text { dimandikan ke } \\
\text { yang sakit }\end{array}$ & Obat lumpuh \\
\hline 37 & Simaroubaceae & Brucea javanica (L.) Merr. & $\begin{array}{l}\text { Buah } \\
\text { Makasar }\end{array}$ & Buah & Dimakan & $\begin{array}{l}\text { Obat menurunkan } \\
\text { kolesterol }\end{array}$ \\
\hline 38 & Thymelaeaceae & $\begin{array}{l}\text { Phaleria macrocarpa (Scheff.) } \\
\text { Boerl. }\end{array}$ & $\begin{array}{l}\text { Mahkota } \\
\text { Dewa }\end{array}$ & Buah & Dimakan & $\begin{array}{l}\text { Obat } \\
\text { mengeluarkan } \\
\text { darah kotor pasca } \\
\text { melahirkan }\end{array}$ \\
\hline 39 & Verbenaceae & $\begin{array}{l}\text { Stachytarpheta jamaicensis (L.) } \\
\text { Vahl }\end{array}$ & Pecut Kuda & Akar & $\begin{array}{l}\text { Direbus dan } \\
\text { airnya diminum }\end{array}$ & Obat asam urat \\
\hline
\end{tabular}


Berdasarkan Tabel 1 terdapat 25 jenis tumbuhan obat yang penggunaannya diminum, enam jenis tumbuhan obat yang penggunaanya dioleskan atau ditempel, empat jenis tumbuhan obat yang penggunaannya dimakan langsung, satu jenis tumbuhan obat yang penggunaannya digunakan untuk mandi (jenis tumbuhan yang digunakan Morinda citrifolia L. dan prosedur yang digunakan direbus dan airnya dimandikan ke orang yang sakit), dua jenis tumbuhan obat yang penggunaanya dicelupkan mata dan satu jenis tumbuhan obat yang penggunaannya dimasukan ke gigi berlubang. Dari semua pemanfaatan, yang paling banyak adalah dengan cara diminum yaitu hampir $50 \%$ dari total pemanfaatan. Sebelum diminum, bagian tumbuhan yang akan digunakan harus direbus terlebih dahulu sebelum bisa diminum. Bagian tumbuhan yang paling banyak digunakan adalah daun karena daun adalah bagian yang paling umum dan paling mudah dalam proses pengolahan. Hal ini sesuai dengan pernyataan Pasorong et al. (2015) menyatakan bahwa daun merupakan bagian yang paling banyak digunakan untuk obat tradisional dibandingkan organ tumbuhan lainnya. Ezimone et al. (2008) juga menjelaskan bahwa daun adalah bagian tumbuhan yang paling banyak digunakan dalam pengobatan tradisonal sebab daun mudah didapatkan dan pengolahannya mudah karena bertekstur lunak dan memiliki kandungan air sekitar 70-80\%.

Famili yang banyak dimanfaatkan masyarakat adalah famili Asteraceae sebanyak enam jenis, dilanjutkan dengan famili Euphorbiaceae sebanyak empat jenis. Famili Asteraceae adalah famili pada kingdom plantae yang memiliki kekayaan jenis nomor dua dari semua famili yang ada pada kingdom plantae (Lawrence 1958). Anggota dari jenis Asteracea sekitar 24.000-30.000 jenis dan 1.600-1.700 genus yang ada tersebar di dunia. Sehingga Asteraceae salah satu famili yang mendominasi hampir di semua lingkungan (Bisht dan Purohit 2010).

Menurut orang pintar/dukun di Desa Pulau Sangkar, tumbuhan dari famili Asteraceae memiliki banyak khasiat seperti Ageratum conyzoides (L.) biasanya digunakan untuk obat kembung, tetapi juga bisa digunakan untuk obat luka. Hal ini sesuai dengan penelitian Singh et al. (2013) menyatakan bahwa $A$. conyzoides bisa digunakan untuk obat demam, kembung, diare dan disentri. Lebih Putra et al. (2013) menyatakan A. conyzoides bisa menghentikan luka yang dicobakan pada mencit. Selain itu, menurut Wegiera et al. 2012, tumbuhan dari Asteraceae dapat dimanfaatkan sebagai obat tradisional, karena pada beberapa jenis famili Asteraceae memiliki komponen senyawa bioaktif, seperti lakton, triterpen pentasiklik, seskuiterpen, alcohol, alkaloid, polifenol, saponin, tannin dan sterol.

Jenis tumbuhan yang digunakan obat oleh masyarakat di Hutan Adat Talang Rencong Desa Pulau Sangkar, Kabupaten Kerinci adalah 39 jenis dari 23 famili. Dari jenis tersebut, tidak ditemukan jenis yang khas pada penelitian ini jika dibandingkan dengan penelitian-penelitian sebelumnya yang pernah dilaksanakan khususnya di Kerinci dan umumnya di Provinsi Jambi dengan rata-rata jenis yang digunakan sebagai tumbuhan obat berkisar antara 30-40 jenis. Penelitian Indriati (2014) tentang tumbuhan obat yang dimanfaatkan Suku Anak Dalam di Desa Tabun Jambi menunjukkan jenis yang digunakan sebagai tumbuhan obat sebanyak 39 jenis. Penelitian Lestari (2011) menunjukkan bahwa Masyarakat Suku Kerinci di sekitar Hutan Adat Bukit Tinggai Desa Sungai Deras Kabupaten Kerinci, Provinsi Jambi memanfaatkan jumlah jenis tumbuhan yang hampir sama yaitu 43 spesies. Sementara Suswita et al. (2013) menyatakan bahwa sebanyak 37 jenis dari 22 famili dimanfaatkan oleh masyarakat di beberapa kecamatan di Kabupaten Kerinci, Jambi digunakan dalam Upacara Adat Kendurisko.

\section{SIMPULAN}

Dari hasil penelitian yang dilakukan di Desa Pulau Sangkar Kecamatan Batang Merangin Kabupaten Kerinci didapatkan 39 jenis dari 23 famili yang dimanfaatkan sebagai tumbuhan obat. Famili Asteraceae adalah famili terbanyak yang digunakan sebagai tumbuhan obat dengan total enam jenis.

\section{DAFTAR PUSTAKA}

Bisht VK, Purohit V. 2010. Medicine and aromatic plants diversity of Asteraceae in Uttarakhand. Nature and Science. 2010:121-128.

Ezimone CO, Nwon CS, Jacson CL. 2008. Cutaneous wound healing activity of a herbal ointment containing the leaf extract of Jatropha Curcas L. International Journal of Applied Reaearch in Natural Products. 1(4):1-4.

Indriati G. 2014. Etnobotani tumbuhan obat yang digunakan Suku Anak Dalam di Desa Tabun Kecamatan VII Koto Kabupaten Tebo Jambi. Jurnal Sainstek. 6(1): 52-56.

Jaini. 1993. Risalah potensi tumbuhan buah-buahan dan tumbuhan sebagai obat pada Kebun Plasma Nutfah di Areal HPH PT. Sari Bumi Kusuma Sintang Kalimantan Barat [skripsi]. Pontianak: Universitas Tanjungpura.

Johnherf. 2007. Jenis Tumbuhan Obat. Diakses di books. google.com/Repasetory.Usu.ac.id.chapter\%201.

Kardinan A, Ruhnayat A. 2003. Budidaya Tanaman Obat Tradisional. Jakarta: Agro Media Pustaka.

Kuni BE, Hardiansyah G, Idham. 2015. Etnobotani Masyarakat Suku Dayak Kerabat di Desa Tapang Perondah Kecamatan Sekadau Hulu Kabupaten Sekadau Pontianak: Universitas Tanjungpura.

Lawrence. 1958. Taxonomi of Vascular Plants. Edisi Ke-3. New York: The Macmillan Company.

Lestari R. 2011. Kajian etnobotani masyarakat Suku Kerinci di sekitar Hutan Adat Bukit Tinggai Desa 
Sungai Deras Kabupaten Kerinci- Provinsi Jambi [skripsi]. Bogor: Institut Pertanian Bogor.

Masyhud. 2010. Lokakarya Nasional Tumbuhan Obat Indonesia.

Http://www.dephut.go.id/index.php/news/details/704 3. Diakses tanggal 27 April 2020.

Pasorong YS, Elis T, Umar RM, Masniawati A. 2015. Identifikasi tumbuhan berkhasiat obat dan potensi pemanfaatannya pada beberapa desa di sekitar Gunung Sesean Kabupaten Toraja Utara. Jurnal Pendidikan FMIPA UNHAS. 1(2):1-12

Putra ATW, Fidiawati WA, Hamidy MY. 2013. Tingkat kepadatan fibroblas pada luka sayat mencit dengan pemberian gel lidah buaya (Aloe chinensis Baker). https://repository.unri.ac.id/handle/123456789/1590.
Singh SB, Devi WR, Marina A, Devi WI, Swapana N, Singh CB. 2013. Ethnobotany, phytochemistry, and pharmacology of Ageratum conyzoides Linn (Asteraceae). J Medic Plants Res. 7(8):371385.

Suswita D, Syamsuardi, Arbain A. 2013. Studi etnobotani dan bentuk upaya pelestarian tumbuhan yang digunakan dalam Upacara Adat Kendurisko di beberapa kecamatan di Kabupaten Kerinci, Jambi. Jurnal BIOLOGIKA. 2(1):67-80.

Wegiera M, Smolarz HD, Jedruch M, Korczak M, Kopron K. 2012. Cytotoxic effect of some medicinal plants from Asteraceae Family on J-45.01 leukemic cell line - Pilot Study. Acta Poloniae PharmaceuticaDrug Research, 69(2):263-268. 